\title{
Status Gizi, Status Kesehatan dan Gaya Hidup pada Wanita Lakto Vegetarian dan Non Vegetarian
}

\section{Nutritional Status, Health Status. and Lifestyle on Lacto Vegetarian and Non Vegetarian Women}

\author{
Widya Astuti ${ }^{1 *}$, Hadi Riyadi ${ }^{1}$, Faisal Anwar ${ }^{1}$, Ni Ketut Sutiari ${ }^{2}$ \\ ${ }^{1}$ Departemen Gizi Masyarakat, Fakultas Ekologi Manusia, Institut Pertanian Bogor \\ ${ }^{2}$ Ilmu Kesehatan Masyarakat, Fakultas Kedokteran, Universitas Udayana \\ (wdyaas@gmail.com)
}

\begin{abstract}
ABSTRAK
Vegetarian diet merupakan salah satu gaya hidup. Tujuan penelitian ini adalah menganalisis perbedaan status gizi, status kesehatan, dan gaya hidup serta menganalisis hubungan status gizi, status kesehatan dengan gaya hidup pada kelompok lakto vegetarian dan nonvegetarian. Desain studi yang digunakan yaitu cross sectional study dengan melibatkan 80 wanita usia 40-65 tahun sebagai subjek yang terbagi menjadi 2 kelompok dan pengambilan data dilakukan di Provinsi Bali. Data analisis menggunakan Man Whitney U Test dan uji hubungan menggunakan Rank Spearman. Penelitian ini didanai oleh Neys-van Hoogstraten Foundation, the Netherlands. Pengumpulan data karaktersit subjek menggunakan kuesioner terstruktur, dan untuk atropometri dilakukan penguran secara langsung. Subjek non vegetarian yang termasuk kedalam kategori obesitas (50\%) dan hipertensi $(37,5 \%)$ lebih tinggi dibandingkan dengan kelompok lakto vegetarian. Sebanyak $70 \%$ subjek lakto vegetarian termasuk kedalam kategori anemia. Hasil penelitian menunjukan adanya perbedaan status gizi, status anemia, dan konsumsi kopi pada kedua kelompok subjek $(\mathrm{p}<0,05)$. Hasil uji hubungan menunjukkan tidak ada hubungan antara status gizi dengan gaya hidup dan status kesehatan dengan gaya hidup pada kelompok lakto vegetarian dan non vegetarian $(p>0,05)$. Penelitian ini menunjukan status gizi, status kesehatan, dan gaya hidup pada kelompok lakto vegetarian lebih baik dibandingkan dengan kelompok non vegetarian. Kelompok lakto vegetarian berisko lebih tinggi terkena anemia.
\end{abstract}

Kata kunci : Anemia, gaya hidup, hipertensi, status gizi, lakto vegetarian

ABSTRACT

Vegetarian diet is one of the lifestyle changes. The aims of this study was to analyse the differences of nutritional status, health status, and lifesytle and to analyse correlation between nutritonal status, health status, with lifestyle in lakto vegetarian groups and non lakto vegetarian groups. The design of this study was cross-sectional study include 80 women aged 40-65 years old and was conducted in Bali Province. Data were analyzed using Man Whitney U Test and difference test and Rank Spearman relationship test. This research was funded by Neys-van Hoogstraten Foundation, the Netherlands. The measurement of characteristic of subjek and lifestyle used questioner. The measuerment of body weight used digital scales. Body height was measurement used staturemater, blood pressure was measurement used sphygmomanometer and Hb levels used cyanmethemoglobin. Nonvegetarian group had higher proportion of obesity and hypertension (50\%; 37,5\%) than lacto vegetarian groups. Lacto vegetarian groups had higher anemia status than non vegetarian groups. The result show there were significant differences between nutritional status and consumption coffee into two groups $(p<0,05)$. There were show no correlation between nutritonal status, health status, with lifestyle ( $p>0.05)$. This study indicates lacto vegetarian group had better nutritional status, health status, and lifestyle than non-vegetarian group. Lacto-vegetarian group had higher risk of anemia.

Keywords : Anemia, lifestyle, hypertension, nutritional status, lacto vegetarian 


\section{PENDAHULUAN}

Awal mula terjadinya vegetarian sebagian besar didasarkan kepada kepercayaan yang di anut. Kepercayaan yang dianut mempunyai aturan agama yang mengatur hal-hal yang diperbolehkan untuk dikonsumsi baik makanan maupun minuman. ${ }^{1}$ Berbagai alasan mendorong seseorang untuk menjadi seorang vegetarian. Alasan-alasan tersebut terkait dengan kesehatan, mempertimbangkan lingkungan dan animals welfare. Saat ini alasan kesehatan bukan menjadi alasan utama untuk menerapkan vegetarian diet. Alasan lain yang menjadikan seseorang vegetarian adalah dari alasan sisi intelektual (ekologi, ekonomi, politik). ${ }^{2}$ Mempertimbangkan masalah kelaparan di dunia, dan alasan kepercayaan dari agama sehingga mengikuti pola makan tersebut. Hal lain yang mendasari seseorang menjadi vegetarian karena adanya perubahan gaya hidup.

Perbedaan gaya hidup dan kebiasaan makan dapat menjadi salah satu cara untuk mencegah terjadinya hipertensi. Perubahan gaya hidup yang dilakukan dapat berupa meningkatkan kebiasaan berolahraga, mengurangi konsumsi alkohol, dan merokok. ${ }^{3}$ Menerapakan plan base diet merupakan salah satu cara untuk mencegah terjadinya hipertensi. Diet vegetarian secara umum mempunyai efek negatif dan positif untuk kesehatan. Rendahnya konsumsi protein hewani berkaitan dengan kecukupan zat besi yang berperan penting dalam pertumbuhan dan fungsi tubuh. ${ }^{4}$ Daging merupakan sumber utama dari hem besi yang dapat diserap secara langsung oleh tubuh dibandingkan dengan non hem besi yang berasal dari tumbuhan. Hal tersebut dapat menjadi salah satu penyebab terjadinya anemia. Selain itu diet vegetarian mempunyai kekurangan dari segi zat gizi lainnya seperti lemak, n-3 PUFA, kalsium, iodium, zink, $\mathrm{Fe}^{2+}$, vitamin B12 dan D. ${ }^{3}$

Serat, magnesium, asam folat, $\mathrm{Fe}^{3+}$, vitamin $\mathrm{C}$ dan E, n-6 polyunsaturated fatty acid (PUFA), antioksidan, karetinoid, flavonoid dan fitokimia lainnya banyak terdapat pada diet vegetarian. ${ }^{3}$ Perubahan pola konsumsi menjadi diet vegetarian dapat menjadi salah satu cara untuk mencegah hipertensi. ${ }^{5,6}$ Vegetarian diet mampu menurunkan asupan natrium dan meningkatkan asupan potasium kebanyakan kedua zat gizi tersebut terkandung didalam pangan nabati. ${ }^{7}$ Menurut Adventisth
Health Study-2 menunjukan lakto vegetarian diet berkaitan dengan penurunan kematian akibat dari penyakit jantung dimana salah satu penyebab terjadinya penyakit jantung adalah hipertensi. ${ }^{5}$ Vegetarian diet mempunyai kelebihan dibandingkan dengan non vegetarian diet. Penurunan tekanan darah nilai efektif dengan menerapakan lakto vegetarian diet. Vegetarian diet mampu menurunkan asupan natrium dan meningkatkan asupan potasium kebanyakan kedua zat gizi tersebut terkandung didalam pangan nabati. ${ }^{5}$

Setiap tahunnya angka hipertensi terus meningkat, data Riskesdas 2018 menunjukkan prevalensi hipertensi di Indonesia tahun 2013 sebesar $25.8 \%$ dan meningkat menjadi $34.1 \%$ di tahun 2018. ${ }^{8}$ Sementara itu menurut penelitian Sukma tahun 2015, menunjukan 93,8\% dari pada kelompok vegetarian termasuk ke dalam kategori anemia. ${ }^{9}$ Oleh karena itu, peneliti bertujuan untuk: 1) menganalisis perbedaan status gizi, gaya hidup, dan status kesehatan pada kelompok subjek lakto vegetarian dan non vegetarian 2) menganalisis hubungan status gizi dengan gaya hidup, dan status kesehatan dengan gaya hidup pada kedua kelompok subjek lakto vegetarian dan non vegetarian.

\section{BAHAN DAN METODE}

Penelitian ini merupakan bagian dari penelitian berjudul judul Dietary Pattern, Protein Quality, Nutritional Status And Health Status In Lakto vegetarian dan Non Lakto vegetarian Community Group In Baliyang didanai oleh Neys-van Hoogstraten Foundation. Desain yang digunakan dalam penelitian ini adalah cross-sectional study. Penelitian dilaksanakan pada bulan Juli sampai dengan Oktober 2018. Penelitian ini bertempat di Provinsi Bali. Pemilihan tempat penelitian berdasarkan adanya komunitas lakto vegetarian dan angka prevalensi hipertensi di Provinsi Bali cukup tinggi. Pengumpulan sample berdasarkan perhitungan rumus besar sampel dengan rata-rata estimasi populasi. Jumlah subjek dalam penelitian ini sebanyak 80 subjek. Subjek dalam penelitian ini terbagi menjadi 2 kelompok yaitu 40 subjek kelompok lakto vegetarian dan 40 kelompok non-lakto vegetarian. Kriteria inklusi yang diterapakan adalah subjek merupakan wanita dengan rentang usia 4065 tahun, untuk kelompok vegetarian menerapkan diet lakto vegetarian. Kriteria eksklusi dari peneli- 
tian ini adalah tidak bersedia mengikuti penelitian dan tidak mengikuti arahan tim peneliti.

Jenis data yang digunakan dalam penelitian ini adalah karakteristik subjek (nama, jenis kelamin, usia, pendidikan terakhir, pekerjaan, dan pendapatan), gaya hidup (kebiasaan berolahraga, kebiasan merokok, kebiasan mengkonsumsi alkohol, dan kebiasan mengonsumsi kopi), antropometri (berat badan dan tinggi badan), dan status kesehatan (tekanan darah dan analisis hemoglobin). Data sosial ekonomi dan gaya hidup diperoleh melalui wawancara dengan subjek menggunakan kuesioner. Pengumpulan data antropometri dilakukan dengan pengukuran secara langsung. Berat badan diukur dengan timbangan sedangkan tinggi badan diukur dengan menggunakan staturemeter. Data tekanan darah dan level hemoglobin subjek dilakukan pengukuran secara langsung menggunakan sphygmomanometerdan cyanmethemoglobin. Proses pengolahan meliputi kegiatan editing, coding, entry, dan cleaning. Pengolahan data dilakukan dengan menggunakan Microsoft Excel 2016 dan dianalisis dengan menggunakan program SPSS version 16.0 for Windows. Analisis univariat dilakukan secara deskriptif untuk menggambarkan sebaran usia, pendidikan terakhir, pekerjaan, pendapatan,kebiasaan berolahraga, kebiasan merokok, kebiasan mengonsumis alkohol, dan kebiasan mengonsumsi kopi, status gizi, dan status kesehatan dari subjek. Analisis biavariat menggunakan uji beda Man Whitney U Test untuk melihat perbedaan status gizi, gaya hidup, dan status kesehatan subjek dan korelasi Rank Spearman untuk melihat hubungan status gizi dengan gaya hidup dan status kesehatan dengan gaya hidup. Penelitian ini telah mendapat persetujuan etik yang berasal dari Komisi Etik Penelitian Fakultas Kedokteran Universitas Udayana/Rumah Sakit Umum Pusat Sanglah Denpasar dengan Nomor: 1004/UN14.2.2/PD/KEP/2018.

\section{HASIL}

Subjek dalam penelitian ini berjumlah 80 subjek. Rata-rata usia dari subjek adalah 51.4 tahun dengan standar deiviasi 6.8. Usia tertua dari subjek yaitu 65 tahun pada kelompok lakto vegetarian dan usia termuda dari subjek adalah 40 tahun pada kelompok non lakto vegetarian. Kelompok non vegetarian mempunyai tingkat pendidikan yang lebih tinggi, dapat terlihat dari jumlah subjek

Tabel 1. Sebaran Subjek Berdasarkan Karakteristik

\begin{tabular}{|c|c|c|}
\hline Variabel & $\begin{array}{c}\text { Lakto Vegetarian } \\
\text { n(\%) }\end{array}$ & $\begin{array}{c}\text { Non-Lakto Vegetarian } \\
\mathbf{n}(\%)\end{array}$ \\
\hline \multicolumn{3}{|l|}{ Pendidikan } \\
\hline Tidak tamat sekolah & $6(15)$ & $1(2.5)$ \\
\hline $\mathrm{SD}$ & $14(35)$ & $6(15)$ \\
\hline SMP & $6(15)$ & $3(7.5)$ \\
\hline SMA & $12(30)$ & $14(35)$ \\
\hline Sarjana & $2(5)$ & $16(40)$ \\
\hline \multicolumn{3}{|l|}{ Pekerjaan } \\
\hline Ibu rumah tangga & $11(27.5)$ & $9(22.5)$ \\
\hline PNS/Polisi/TNI & $4(10)$ & $0(0)$ \\
\hline Karyawan swasta & $3(7.5)$ & $0(0)$ \\
\hline Wiraswasta & $13(32.5)$ & $20(50)$ \\
\hline Jasa & $6(15)$ & $4(10)$ \\
\hline Petani/Nelayan & $0(0)$ & $1(2.5)$ \\
\hline Buruh & $0(0)$ & $3(7.5)$ \\
\hline Lainnya & $3(7.5)$ & $3(7.5)$ \\
\hline \multicolumn{3}{|l|}{ Pendapatan } \\
\hline $\begin{array}{l}\text { Miskin } \\
(<\text { Rp371 118/kap/bln) }\end{array}$ & $4(10)$ & $2(5)$ \\
\hline 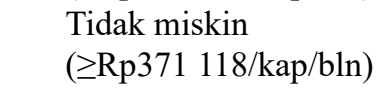 & $36(90)$ & $38(90)$ \\
\hline Rata-rata \pm SD & Rp $1833970 \pm 1355681$ & Rp $1231626 \pm 679225$ \\
\hline
\end{tabular}

Sumber: Data Primer, 2019 
Tabel 2. Uji Beda Gaya Hidup, Status Gizi, dan Status Kesehatan

\begin{tabular}{|c|c|c|c|}
\hline Variabel & $\begin{array}{c}\text { Lakto Vegetarian } \\
\text { n }(\%)\end{array}$ & $\begin{array}{c}\text { Non Vegetarian } \\
\mathbf{n}(\%)\end{array}$ & p* \\
\hline \multicolumn{4}{|l|}{ Gaya hidup } \\
\hline Kebiasaan olahraga & $17(42.5)$ & $25(37.5)$ & 0.075 \\
\hline Kebiasaan merokok & $0(0)$ & $2.0(5.0)$ & 0.155 \\
\hline Kebiasaan konsumsi kopi & $0(0)$ & $26(65)$ & $0.000 *$ \\
\hline \multicolumn{4}{|l|}{ Status Gizi } \\
\hline \multicolumn{4}{|l|}{ Indeks Massa Tubuh (IMT) } \\
\hline Normal & $20(50)$ & $10(25)$ & $0.041 *$ \\
\hline Overweight & $11(27.5)$ & $14(35)$ & \\
\hline Obesitas & $9(22.5)$ & $16(40)$ & \\
\hline \multicolumn{4}{|l|}{ Status Anemia } \\
\hline Normal $(\mathrm{Hb}>12 \mathrm{~g} / \mathrm{dl})$ & $10(25)$ & $38(95)$ & $0.000 *$ \\
\hline Anemia $(\mathrm{Hb}<12 \mathrm{~g} / \mathrm{dl})$ & $30(75)$ & $2(5)$ & \\
\hline \multicolumn{4}{|c|}{ Status Kesehatan (sistol/diastol) } \\
\hline Normal $(120 / 80)$ & $28(70)$ & $25(62.5)$ & 0.481 \\
\hline Hipertensi $(\geq 120 / \geq 80)$ & $12(30)$ & $15(37.5)$ & \\
\hline
\end{tabular}

Sumber: Data Primer, 2019

Tabel 3. Uji Hubungan Status Gizi, Status Kesehatan, dengan Gaya Hidup

\begin{tabular}{lcccc}
\hline \multirow{2}{*}{ Variabel } & \multicolumn{2}{c}{ Lakto vegetarian } & \multicolumn{2}{c}{ Non vegetarian } \\
\cline { 2 - 5 } & $\mathbf{r}$ & $\boldsymbol{p}$-value & $\mathbf{r}$ & $\boldsymbol{p}$-value \\
\hline Status Gizi & & & & 0.073 \\
$\quad$ Kebiasaan olahraga & 0.119 & 0.464 & 0.286 & 0.845 \\
Kebiasaan merokok & -0.247 & 0.124 & -0.032 & 0.859 \\
$\quad$ Kebiasaan konsumsi kopi & - & - & -0.029 & 0.080 \\
Status Kesehatan & & & & 0.280 \\
$\quad$ Kebiasaan olahraga & -0.121 & 0.456 & 0.296 & 0.868 \\
Kebiasaan merokok & -0.247 & 0.124 & 0.270 & \\
Kebiasaan konsumsi kopi & - & - & & \\
\hline
\end{tabular}

Sumber: Data Primer, 2019

yang mempunyai ijazah 14 orang (35\%) dan sarjana sebanyak 16 orang $(40 \%)$ lebih banyak dibandingkan dengan kelompok lakto vegetarian. Wirasawasta merupakan profesi terbanyak yang digeluti oleh subjek sebanyak 13 orang $(32.5 \%)$ pada kelompok lakto vegetarian dan 20 orang $(50 \%)$ pada kelompok non vegetarian (Tabel 1).

Hasil analisis menunjukan subjek mempunyai kebiasaan berolahraga sebanyak 17 orang (42.5\%) pada kelompok lakto vegetarian dan 25 orang $(37.5 \%)$ pada kelompok non vegetarian. Frekuensi rata-rata kedua kelompok subjek yang melakukan olahraga yaitu sebanyak 3 kali dengan rata-rata durasi 0.4 jam perhari dengan standar deviasi 0.5. Kelompok lakto vegetarian tidak mempunyai kebiasaan merokok, terdapat 2 orang (5\%) subjek non vegetarian yang mempunyai kebiasaan merokok. Subjek non vegetarian mem- punyai kebiasan mengonsumsi kopi sebanyak 26 orang (65\%). Hasil uji beda Man Whitney U Test menunjukkan terdapat perbedaan kebiasaan mengonsumsi kopi yang siginfikan $(\mathrm{p}<0.05)$ antara kedua kelompok subjek (Tabel 2).

Hasil uji beda Man Whitney U Test menunjukkan terdapat perbedaan status gizi yang signifikan $(\mathrm{p}<0.05)$ antara dua kelompok subjek. Subjek yang termasuk kedalam status gizi kategori normal sebanyak 20 orang $(50 \%)$ berasal dari kelompok subjek lakto vegetarian. Sebanyak 16 orang $(40 \%)$ dari subjek non vegetarian termasuk kategori obesitas. Hasil analisis darah kedua kelompok subjek, menunjukan subjek lakto vegetarian yang mempunyai nilai $\mathrm{Hb}<12 \mathrm{~g} / \mathrm{dl}$ atau termasuk ke dalam kategori anemia sebanyak 30 orang (75\%) lebih tinggi dibandingkan dengan subjek non vegetarian. Hasil uji beda dari kedua 
kelompok menunjukkan adanya perbedaan status anemia yang signifikan $(\mathrm{p}<0.05)$. Hasil analisis menunjukan subjek yang termasuk ke dalam kategori hipertensi terbanyak berasal dari kelompok subjek non vegetarian yaitu sebanyak 15 orang (37.5\%). Sebagian besar dari kelompok subjek lakto vegetarian termasuk kedalam katergori nomal (70\%). Hasil uji beda Man Whitney U Test menunjukkan tidak adanya perbedaan yang signifikan $(\mathrm{p}>0.05)$ antara tekanan darah pada kedua kelompok subjek (Tabel 2).

Uji hubungan Rank Spearman menunjukkan negatif signifikan $(\mathrm{p}>0.05)$ antara status gizi degan status kesehatan pada kedua kelompok subjek. Hasil uji hubungan Rank Spearman menunjukan terdapat hubungan negatif yang signifikan $(\mathrm{p}>0.05)$ antara status gizi, status kesehatan dengan gaya hidup pada kelompok lakto vegetarian $(\mathrm{p}=0.464$ $\mathrm{r}=0.119 ; \mathrm{p}=0.124 \quad \mathrm{r}=0.247 ; \mathrm{p}=0.456 \quad \mathrm{r}=0.212 ;$ $\mathrm{p}=0.124, \mathrm{r}=0.247$ ) maupun pada kelompok non vegetarian $(\mathrm{p}=0.073 \mathrm{r}=0.286 ; \mathrm{p}=0.845 \mathrm{r}=0.032$; $\mathrm{p}=0.080 \mathrm{r}=0.280 ; \mathrm{p}=0.064 \mathrm{r}=0.296)$ (Tabel 3$)$

\section{PEMBAHASAN}

Perbedaan tingkat pendidikan antara kedua kelompok, dapat menjadi salah satu faktor yang mempengaruhi terjadinya hipertensi. Hal ini berkaitan dengan gaya hidup yang diterapkan dalam kehidupan sehari-hari. Pendidikan yang rendah pada subjek dapat berpengaruh terhadap pengetahuan sehingga berpengaruh terhadap perilaku dan pola hidup sehat. ${ }^{10}$ Penelitian menunjukan rata-rata usia subjek kelompok lakto vegetarian lebih tinggi dibandingkan dengan kelompok non vegetarian. Kejadian hipertensi dalam penelitian ini lebih tinggi pada kelompok non vegtarian. Berbeda dengan penelitian, Ekowati et al., tahun 2009 menyatakan seiring bertambahnya usia risiko hipertensi akan meningkat. ${ }^{11}$ Seluruh subjek dalam penelitian ini berjenis kelamin perempuan. Resiko hipertensi lebih tinggi terjadi pada laki-laki. ${ }^{11}$ Berbeda halnya penelitian menunjukkan prevalensi hipertensi lebih tinggi pada subjek berjenis kelamin perempuan..$^{12}$ Kedua kelompok subjek termasuk ke dalam kategori tidak miskin, rata-rata pendapatan perkapita subjek $\geq$ Rp371 118/kap/bln (Tabel 1).

Gaya hidup meliputi kebiasaan olahraga, kebiasaan merokok, kebiasaan mengonsumsi kopi, dan kebiasaan mengonsumsi alkohol merupakan faktor lain yang dapat meningkatkan hipertensi. ${ }^{13}$ Kedua kelompok dalam penelitian ini mempunyai kebiasaan olahraga yang cukup baik. Kurangnya olahraga rutin dapat meningkatkan risiko hipertensi. ${ }^{10,11,13}$ Penelitian ini menunjukan adanya perbedaan kebiasaan mengonsumsi kopi pada kedua kelompok subjek. Hal ini disebabkan adanya larangan agama yang tidak memperbolehkan mengonsumsi kopi pada kelompok subjek lakto vegetarian. Kopi dianggap sebagai bahan pangan yang dapat menimbulkan penyakit dan kecanduan apabila dikonsumsi. Kopi merupakan minuman yang dianggap tidak baik untuk kesehatan karena menimbulkan gangguan lambung, diabetes, hipertensi dan mengandung kafein yang membuat kecanduan. ${ }^{14}$ Kedua kelompok subjek tidak mempunyai kebiasaan dalam mengonsumsi alkohol. Kedua kelompok beralasan tidak mengonsumsi alkohol karena menimbulkan efek kecanduan dan tidak baik untuk kesehatan. Mengurangi konsumsi alkohol merupakan salah satu pecegahan terjadinya hipertensi. ${ }^{15-17}$ Larangan agama merupakan salah satu alasan subjek lakto vegetarian tidak mengonsumsi alkohol (Tabel 2).

Vegetarian diet telah menjadi pola makan yang mulai banyak dipilih masyarakat seiring dengan meningkatnya pengetahuan masyarakat akan manfaat pola makan berbasis pangan nabati dalam mengurangi resiko penyakit degeneratif. ${ }^{18}$ Perbedaan status gizi pada kedua kelompok disebabkan adanya perbedaan pemilihan jenis pangan yang dikonsumsi. Pemilihan jenis pangan yang akan dikonsumsi oleh seseorang akan mempengaruhi asupan dan tingkat kecukupan zat gizi. Perbedaan status gizi dari kedua kelompok subjek menunjukan adanya pengaruh dari kebiasaan makan terhadap status gizi. Menurut Riyadi tahun 2006 status gizi menggambarkan keadaan kesehatan seseorang atau kelompok yang diakibatkan oleh konsumsi, penyerapan, dan penggunaan zat gizi pangan. ${ }^{19}$ Faktor gizi akan mempengaruhi status gizi secara langsung yaitu konsumsi pangan dan keadaan kesehatan. Kebiasaan makan tinggi asupan buah dan sayur pada kelompok lakto vegetarian merupakan salah satu faktor yang mempengaruhi status gizi. Sebagaimana diketahui buah dan sayur merupakan pangan sumber serat dan vitamin. Hal lain yang menjadi faktor tingginya asupan lemak yang dikonsumsi oleh subjek non vegetarian. Hal ini se- 
jalan dengan penelitian yang menyatakan adanya perbedaan status gizi individu yang mengonsumsi daging mempunyai asupan energi total lebih tinggi dan status gizi inidividu tersebut termasuk kategori obesitas. ${ }^{6,20}$ Terdapatnya perbedaan status anemia pada kedua kelompok dan tingginya kelompok subjek lakto vegetarian yang mempunyai status anemia disebabkan oleh perbedaan pola konsumsi. Kelompok lakto vegetarian mempunyai kebiasaan makanan yang tidak mengonsumsi pangan protein hewani. Pangan hewani merupakan pangan yang mengadung zat besi lebih tinggi dari pangan protein nabati. Hal ini sejalan dengan penelitian yang dilakukan Amitava et al., tahun 2014 tingginya prevalensi anemia pada kelompok lakto vegetarian disebabkan rendahnya konsumsi pangan sumber zat besi. ${ }^{21}$ Selain itu tingginya asupan zat seperti fitat, oksalat, karbonat, fosfat, dan serat makan dapat mengganggu proses penyerapan zat besi. ${ }^{22}$

Penelitian tidak menunjukkan adanya perbedaan status kesehatan (tekanan darah) antara kedua kelompok. Jumlah subjek yang mengalami hipertensi pada subjek non vegetarian lebih tinggi dibandingkan dengan lakto vegetarian. Tingginya konsumsi pangan sumber lemak, dan natrium pada subjek non vegetarian merupakan salah satu penyebabnya. Asupan natrium berkaitan dengan peningkatan tekanan darah. ${ }^{23,24}$ Diet vegetarian berkaitan dengan menurunkan tekanan darah baik sistolik maupun tekanan darah diastolik. ${ }^{16}$ Penelitian lain menemukan ketebalan intima media lebih tipis pada subjek lakto vegetarian dibandingkan nonvegtarian, hal ini menunjukan adanya efek positif yang baik untuk fungsi sel endotel dan otot polos pada pembuluh darah sehingga membuat arteri menjadi lebih elastis. ${ }^{25,26}$ Selain asupan makan riwayat keluarga dapat menjadi salah satu faktor resiko dari terjadinya hipertensi. Sebanyak $17.5 \%$ subjek kelompok non vegetarian mempunyai riwayat keluarga hipertensi.

Uji hubungan dalam penelitian ini tidak menunjukan adanya hubungan status gizi dengan gaya hidup (kebiasaan olahraga, kebiasaan merokok, kebiasaan mengonsumsi kopi, dan kebiasaan mengonsumsi alkohol) pada kedua kelompok. Kedua kelompok subjek mempunyai kebiasaan olahraga yang sama baik durasi maupun frekuensi dalam berolahraga. Hasil yang sama didapatkan dari uji hubungan status kesehatan dengan gaya hidup (kebiasaan olahraga, kebiasaan merokok, kebiasaan mengonsumsi kopi, dan kebiasaan mengonsumsi alkohol). Berbeda halnya dengan hasil penelitian Anggara et al., tahun 2013, yang menyatakan seseorang yang teratur berolahraga akan terhidar dari resiko hipertensi 44,1 kali dibadingkan dengan yang tidak rutin berolahraga. ${ }^{10}$ Menurut Rahajeng, melakukan aktivitas fisik secara teratur dapat menurunkan resiko hipertensi $19-30 \% .^{12}$ Hasil penelitian ini sejalan dengan hasil penelitian dan Ruth et al., tahun 2015, yang menunjukan tidak ada hubungan antara kebiasaan olahraga, kebiasaan merokok, dan konsumsi alkohol dengan kejadian hipertensi. ${ }^{27}$ Hasil yang berbeda ditunjukan oleh penelitian Pradeep dan Diplee tahun 2013, adanya hubungan antara kebiasaan minum kopi dengan tekanan darah yang ditunjukan dengan adanya peningkatan darah sistolik pada subjek setelah diberikan perlakuan. ${ }^{15}$

\section{KESIMPULAN DAN SARAN}

Penelitian ini menunjukan subjek lakto vegetarian mempunyai status gizi (indeks massa tubuh) dan status kesehatan yang lebih baik daripada kelompok non vegetarian. Status anemia pada kelompok lakto vegetarian lebih tinggi dibandingkan dengan kelompok non vegetarian, yang disebabkan oleh rendahnya konsumsi pangan sumber protein hewani. Gaya hidup dari kelompok subjek lakto vegetarian lebih baik daripada kelompok non vegetarian ditandai dengan tidak adanya subjek yang mengonsumsi kopi dan alkohol dan tidak mempunyai kebiasaan merokok. Hal ini terjadi karena adanya larangan agama yang dianut oleh subjek. Tidak adanya hubungan antara status gizi, status kesehatan dengan gaya hidup disebabkan kedua kelompok subjek mempunyai kebiasaan olagraga yang sama baik frekuensi dan durasi dalam berolahraga. Hasil penelitian ini diharapkan dapat digunakan oleh pemerintah sebagai pencegahan hipertensi dan menjadi upaya pencegahan anemia untuk masyarakat yang menerapkan lakto vegetarian diet. Kelompok subjek lakto vegetarian harus lebih memperhatikan jenis dan jumlah pangan yang dikonsumsi terutama dalam pemilihan pangan sumber protein nabati. Pemilihan jenis pangan yang tepat dapat membantu penyerapan zat besi yang dibutuhkan. Mengonsumsi vitamin B12 dapat menjadi salah satu cara meningkatkan 
asupan pada kelompok lakto vegetarian.

\section{UCAPAN TERIMAKASIH}

Penulis mengucapkan terimakasih kepada Neys-van Hoogstraten Foundation, the Netherlands yang telah mendanai penelitian ini.

\section{DAFTAR PUSTAKA}

1. Sabaté J. Vegetarian Nutrition. Boca Raton: CRC Press; 2001.

2. Leitzmann C. Postoperative Nutrition: Past, Present, and Future. Am J Clin Nutr. 2014;100(1):496S-502S.

3. Li D. Effect of The Vegetarian Diet on Non-communicable Diseases. J Sci Food Agric. 2014;94(2):169-73.

4. Craig WJ. Nutrition Concerns and Health Effects of Vegetarian Diets. Nutr Clin Pract. 2010;25(6):613-20.

5. Orlich M, Singh P, Sabaté J, Jaceldo-Siegl K, Fan J, Knutsen S, et al. Vegetarian Dietary Patterns and Mortality in Adventist Health Study 2. JAMA Intern Med. 2013;173(13):1230-8.

6. Chuang SY, Chiu THT, Lee CY, Liu TT, Tsao CK, Hsiung CA, et al. Vegetarian Diet Reduces the Risk of Hypertension Independent of Abdominal Obesity and Inflammation: A Prospective Study. J Hypertens. 2016;34(11):2164-71.

7. Craig WJ. Vegetarian Nutrition and Wellness. Boca raton: CRC Press; 2018.

8. Kementerian Kesehatan Republik Indonesia. Hasil Utama Riskesdas 2018. Jakarta; 2018.

9. Sukma IWB, Dewantari NM, Kusumajaya AAN. Pola Konsumsi dan Status Anemia pada Vegetarian Vegan. J Ilmu Gizi. 2015;6(2):1217.

10. Anggara F, Prayitno N. Faktor-Faktor yang Berhubungan dengan Tekanan Darah di Puskesmas Telaga Murni Cikarang Barat Tahun 2012. J Ilm Kesehat. 2013;5(1):20-5.

11. Rahajeng E, Tuminah S. Prevalensi Hipertensi dan Determinannya di Indonesia. Maj Kedokt Indon. 2009;59(12):580-7.

12. Arifin MHBM, Weta IW, Ratnawati NLKA. Faktor-Faktor yang Berhubungan dengan Kejadian Hipertensi pada Kelompok Lanjut Usia di Wilayah Kerja UPT Puskesmas Petang I Kabupaten Badung Tahun 2016. E-Jurnal
Med. 2016;5(7):18-45.

13. Saputra O, Anam K. Gaya Hidup sebagai Faktor Risiko Hipertensi pada Masyarakat Pesisir Pantai. J Major. 2016;5(3):118-23.

14. Rahmawati R, Daniyati D. Hubungan Kebiasaan Minum Kopi terhadap Tingkat Hipertensi. J Ners Community. 2016;7(2):149-61.

15. Kumar P, Verma DK, Narayan J, Kanawjia P, Ghildiyal A. Effect of Coffee on Blood Pressure and Electrocardiographic Changes in Nicotine Users. Asian J Med Sci. 2014;6(3):46-8.

16. Skliros EA, Papadodima SA, Sotiropoulos A, Xipnitos C, Kollias A, Spiliopoulou CA. Relationship Between Alcohol Consumption and Control of Hypertension Among Elderly Greeks. The Nemea Primary Care Study. Hellenic J Cardiol. 2012;53(1):26-32.

17. Husain K, Ansari RA, Ferder L. Alcohol-induced Hypertension: Mechanism and Prevention. World J Cardiol. 2017;6(5):245.

18. Anggraini L, Lestariana W, Susetyowati S. Asupan Gizi dan Status Gizi Vegetarian pada Komunitas Vegetarian di Yogyakarta. J Gizi Klin Indones. 2017;11(4):143.

19. Riyadi H. Gizi dan Kesehatan Keluarga. Jakarta: Universitas Terbuka; 2006.

20. Wang Y, Beydoun MA. Meat Consumption is Associated with Obesity and Central Obesity among US Adults. Int J Obes [Internet]. 2009;33(6):621-8. Tersedia pada: http://dx. doi.org/10.1038/ijo.2009.45.

21. Pal A, De S, Sengupta P, Maity P, Dhara PC. An Investigation on Prevalence of Anaemia in Relation to BMI and Nutrient Intake among Adult Rural Population of West Bengal, India. Epidemiol Biostat Public Heal. 2014;11(2):110.

22. Nair K, Iyengar V. Iron Content, Bioavailability \& Factors Affecting Iron Status of Indians. Indian J Med Res. 2009;130(5):634-45.

23. Stolarz-Skrzypek K, Kuznetsova T, Thijs L, Tikhonoff V, Seidlerová J, Richart T, et al. Fatal and Nonfatal Outcomes, Incidence of Hypertension, and Blood Pressure Changes in Relation to Urinary Sodium Excretion. JAMA - J Am Med Assoc. 2011;305(17):1777-85.

24. Erdem Y, Arici M, Altun B, Turgan C, Sindel S, Erbay B, et al. The Relationship Between Hypertension and Salt Intake in Turkish 
Population: SALTURK study. Blood Press. 2010;19(5):313-8.

25. Yang SY, Li XJ, Zhang W, Liu CQ, Zhang HJ, Lin JR, et al. Chinese Lacto-Vegetarian Diet Exerts Favorable Effects on Metabolic Parameters, Intima-Media Thickness, and Cardiovascular Risks in Healthy Men. Nutr Clin Pract. 2012;27(3):392-8.

26. Yang S., Zhang H., Sun SY, Wang LY, Yan
B, Liu CQ, et al. Relationship of Carotid Intima-Media Thickness and Duration of Vegetarian Diet in Chinese Male Vegetarians. Nutr Metab. 2011;8(1):63-9.

27. Wulandari RA, Madanijah S. Gaya Hidup, Komsumsi Pangan, dan Hubungannya dengan Tekanan Darah pada Lansia Anggota Posbindu. J Gizi dan Pangan. 2015;10(2):125-32. 